\title{
Relationships between methods of variety adaptability and stability in sugarcane
}

T.O. Mendes de Paula ${ }^{1}$, C.D. Marinho², V. Souza ${ }^{2}$, M.H.P. Barbosa ${ }^{1}$, L.A. Peternelli' ${ }^{2}$ C.A. Kimbeng ${ }^{3}$ and M.M. Zhou ${ }^{4}$

${ }^{1}$ Departamento de Fitotecnia, Universidade Federal de Viçosa, Viçosa, MG, Brasil ${ }^{2}$ Departamento de Estatística, Universidade Federal de Viçosa, Viçosa, MG, Brasil ${ }^{3}$ School of Plant, Environmental and Soil Science, Louisiana State University Agricultural Center, Baton Rouge, LA, USA

${ }^{4}$ South African Sugarcane Research Institute, Mount Edgecombe, KwaZulu-Natal, South Africa

Corresponding author: C.D. Marinho

E-mail: caillet.marinho@yahoo.com.br

Genet. Mol. Res. 13 (2): 4216-4225 (2014)

Received April 24, 2013

Accepted November 1, 2013

Published June 9, 2014

DOI http://dx.doi.org/10.4238/2014.June.9.7

\begin{abstract}
The identification and recommendation of superior genotypes is crucial for the growth of industrial crops, and sugarcane breeding performs a vital role by developing more productive cultivars. The study of genotype x environment interaction has been an essential tool in this process. Thereby, the purpose of this study was to investigate the relationship between methods of adaptability and stability in sugarcane. Data were collected from trials using a randomized block design with three repetitions and 15 clones of sugarcane in nine environments in the State of Minas Gerais, Brazil. Methodologies based on analysis of variance, linear regression, multivariate analysis, nonparametric statistics, and mixed model were used. The methods of Lin and Binns, Annicchiarico, and harmonic mean of relative performance of genotypic values (MHPRVG) were similar in their classification of genotypes. The additive main effect and multiplicative interactions (AMMI) and Wricke methods tended to select the most stable genotypes; however,
\end{abstract}


genotypes were less productive, coinciding with the stability parameter of Eberhart and Russell. The MHPRVG method is preferred over the methods of Lin and Binns and Annicchiarico because it includes the concepts of productivity, adaptability, and stability, and it provide direct genetic values of individuals. The use of the MHPRVG and Eberhart and Russell methods is recommended because the combination of these methods is complementary and leads to greater accuracy in the identification of genotypes of sugarcane for different environments.

Key words: Genotype x environment interaction; Sugarcane breeding; Mixed model; Multi-environment trials; Saccharum spp

\section{INTRODUCTION}

The production of sugarcane plays a crucial role in Brazil's economy, and its importance has been growing, especially with the interest in obtaining renewable energy sources. In the 2011/2012 harvest, sugarcane was cultivated on about 9 million hectare, from which about 560 million tons of sugarcane was produced, which corresponds to an average yield of 63 tons per hectare (CONAB, 2012). To meet the growing global demand for sugar and ethanol, it is necessary not only to incorporate new areas of production but also increase productivity.

Sugarcane breeding performs a vital role by developing more productive cultivars. The breeding program of sugarcane, Rede Interuniversitária para o Desenvolvimento do Setor Sucroalcooleiro (RIDESA), developed varieties with the letters RB (Republic of Brazil) for the different environments of Brazil, thus contributing to the growth of the sugarcane agribusiness nationally. Among the varieties released by RIDESA, cultivar RB867515 is currently the most widely grown in various regions of Brazil, covering $22 \%$ of the national area (Barbosa et al., 2012; dos Santos et al., 2012).

The economic return provided by this crop depends heavily on the cultivar productivity. Cultivars help maintain production over several years. Thus, the steps that are used to assess, identify, and recommend superior genotypes are crucial for the growth of industrial crops. The study of genotype $\mathrm{x}$ environment (GE) interaction has been an essential tool in this process because it analyzes the existence of differential behavior of genotypes in different environments (Verissimo et al., 2012). If there is a complex GE interaction, one seeks to find the performance of genotypes for adaptability and stability. Adaptability refers to the ability of the genotypes to advantageously harness the environmental stimulus, and stability refers to a highly predictable behavior of the genotypes to environmental changes (Cruz et al., 2012).

Therefore, different procedures have been used to evaluate the stability and adaptability in breeding programs. Deciding which method is more efficient to design genotypes that are adaptive and stable is not always an easy task. Different methods have been compared using different crops such as soybean (Rocha et al., 2006), bean (Pereira et al., 2009), wheat (Mohammadi and Amri, 2008), popcorn (Scapim et al., 2010), and rubber tree (Gouvêa et al., 2012). According to Cargnelutti Filho et al. (2007) methods can be arranged in classes: those based on analysis of variance, linear regression, multivariate analysis, and nonparametric statistics. The methods of Wricke (1965), Eberhart and Russell (1966), additive main effect and multiplicative interactions (AMMI) (Zobel et al., 1988), and Lin and Binns (1988) are exam- 
ples of each class, respectively. In addition, there are also mixed model methodologies, such as the method of harmonic mean of the relative performance of genotypic values (MHPRVG), which is recommended by Resende (2007a).

Because several methods have been used to study the adaptability and stability in sugarcane and few articles have reported comparisons between methods that belong to different classes, such a study is required. Thus, the objective of this study was to investigate the relationship between different methods of adaptability and stability in sugarcane.

\section{MATERIAL AND METHODS}

The experiments were conducted in a randomized complete-block design with three replications and 15 genotypes. The trials were established between February and March 2004. The experimental unit consisted of four rows that were $10 \mathrm{~m}$ long with a spacing of $1.40 \mathrm{~m}$ between rows and a distribution of 18 buds per linear meter that were planted manually. The locations (Minas Gerais State, Brazil) are described in Figure 1.

The sugarcane stalks were harvested in August 2005 (plant cane) and in the same

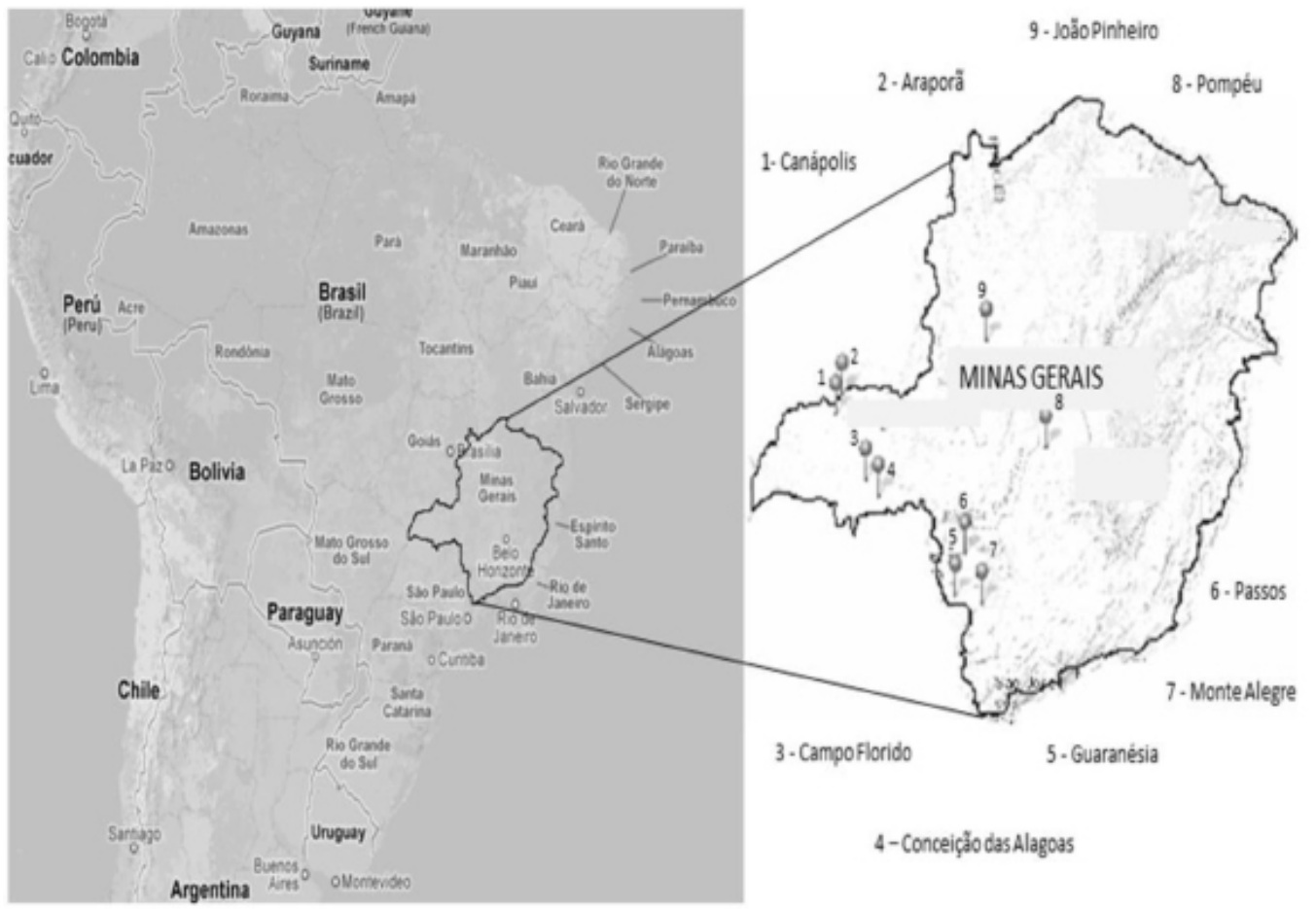

Figure 1. Locations (Minas Gerais State, Brazil) where the experiments were conducted with 15 genotypes of sugarcane in the crop seasons 2004/2005 and 2005/2006.

month in 2006 (first ratoon). Weighing was done in the field using a dynamometer. From the values of the weight of stalks ( $\mathrm{kg}$ ) per plot, tons of stalks per hectare (TSH) were estimated. 
The pol content (PC) was obtained from juice analysis of 10 stalks from each plot. Therefore, the variable ton of pol per hectare (TPH) was obtained as follows: TPH $=(\mathrm{TSH} \times \mathrm{PC}) / 100$.

The analyses were performed using the mean values of TPH that were obtained from the plant cane and first ratoon. The analysis of variance was performed considering the effect of genotype as fixed and that of environment as random, according to the following statistical model: $Y_{i j k}=m+B / E_{j k}+G_{i}+E_{j}+G E_{i j}+\varepsilon_{i j k}$, where $Y_{i j k}$ represents the $i$ th genotype in the $j$ th environment and the $k$ th block, $m$ is the overall mean, $B / E_{j k}$ corresponds to the block within the $j$ th environment in the $k$ th block, $G_{i}$ is the effect of the $i$ th genotype, $E_{j}$ is the effect of the $j$ th environment, $G E_{i j}$ is the effect of interaction of the $i$ th genotype with the $j$ th environment, and $\varepsilon_{i j k}$ is the effect of experimental error. The combined analysis of variance was performed after determining the homogeneity of the residual mean squares, where the ratio between the highest and lowest residual mean square was not more than seven (Cruz et al., 2012).

The analysis of adaptability and stability were performed using the methods by Wricke (1965), Annicchiarico (1992), Eberhart and Russell (1966), Lin and Binns (1988), AMMI (Zobel et al., 1988), and MHPRVG (Resende, 2007a). The first three methods used the statistical GENES software (Cruz, 2006) of the Universidade Federal de Viçosa (UFV). The SAS software (SAS Institute, 2002) was used for AMMI analysis, and the Selegen-REML/BLUP software (Resende, 2007b) of the Brazilian Agricultural Corporation EMBRAPA was used for the other two methods.

The mean of stability of genotypes by the Wricke (1965) method was estimated by $W_{i}=\sum_{j=1}^{n}\left(g_{\varepsilon}\right)_{i}^{2}$, using $\left(g_{\varepsilon}\right)_{i j}=Y_{i j}-\bar{Y}_{i .}-\bar{Y}_{j}-\bar{Y}$, where $Y_{i j}$ is the mean of genotype $i$ in environment $j, Y_{i}$ is the mean of genotype $i$ in all environments, $Y_{j}$ is the mean of environment $j$ for all the genotypes, $Y$ is the general mean, $g$ is the number of genotypes accessed, and $e$ is the number of environments.

Annicchiarico (1992) proposed the calculation of a risk index for each genotype $\left(I_{i}\right)$ as a measure of stability, which is given by $I_{i}=Y_{i}-Z(1-\alpha) S_{i}$, where $I_{i}$ is the confidence index (\%), $Y_{i}$ is the average of the genotype i expressed as a percentage, $Z$ is the percentile $(1-\alpha)$ of the cumulative normal distribution function, and $S_{1}$ is the standard deviation of earnings. The confidence interval was $75 \%$, or $\alpha=0.25$.

The model used for Eberhart and Russell (1966) analysis was: $Y_{i j}=\beta_{0}+\beta_{1} I_{j}+\sigma_{i j}^{2}+e_{i j}$, where $Y_{i j}$ is the observed mean of genotype $i$ in environment $j, \beta_{0}$ is the general mean of genotype $i, \beta_{1}$ is the coefficient of regression of genotype $i, I_{j}$ is the environmental index $j, \sigma_{I J}^{2}$ is the deviation of the regression of genotype $i$ in environment $j$, and $e_{i j}$ is the mean error associated with the average. The environmental index was calculated by $I_{j}=\bar{Y}_{. j}-\bar{Y}_{. .}$, with $\sum_{j=1}^{n} I_{j}=0$, where $n$ is the number of environments.

Lin and Binns (1988) used the following estimator of phenotypic stability: $P_{i}=\sum_{j=1}^{n}\left(X_{i j}-M_{j}\right)^{2} / 2 n$, where $P_{i}$ is the index of superiority of the $i$ th cultivar, $X_{i j}$ is the yield of the $i$ th cultivar at environment $j, M_{j}$ expresses the maximum response obtained among all cultivars at environment $j$, and $n$ represents the number of environments. This expression was partitioned in $P_{i}=\left[n\left(X_{i .}-\bar{M}\right)^{2}+\sum_{j=1}^{n}\left(X_{i j}-\bar{X}_{i .}-M_{j}+\bar{M}\right)^{2}\right] / 2 n$, where $X_{i}$ is the mean yield of cultivar $i$ obtained in $n$ environments, and $\underline{M}$ is the mean of the maximum responses of all cultivars in all environ- 
ments. The first term of the equation represents the sum of squares related to the genetic effect, and the second term represents the sum of squares of the GE interaction.

The AMMI method, as described in Zobel et al. (1988) used the following statistical model: $Y_{i j}=\mu+g_{i}+e_{j}+\sum_{k-n}^{n} \lambda_{k} \alpha_{i k} y_{j k}+r_{i j}+\varepsilon_{i j}$, where $Y_{i j}$ is the mean response of genotype $i$ in the environment $j, \mu$ is the overall mean, $g_{i}$ is the fixed effect of genotype $i(i=1,2, \ldots, g), e_{i}$ is the random effect of environment $j(j=1,2, \ldots, \mathrm{e}), \varepsilon_{i j}$ is the average experimental error, the GE interaction is represented by the factors, $\lambda_{k}$ is a unique value of the $k$ th interaction principal component analysis (IPCA) ( $k=1,2, \ldots, p$, where $p$ is the maximum number of estimable main components), $\alpha_{i k}$ is a singular value for the $i$ th genotype in the $k$ th IPCA, $y_{j k}$ is a unique value of the $j$ th environment in the $k$ th IPCA, $r_{i j}$ is the error for the GE interaction or AMMI residue (noise present in the data), and $k$ is the characteristic non-zero roots where $k=[1,2, \ldots, \min (\mathrm{G}-1, \mathrm{E}-1)]$.

The method described by Resende (2007a) refers to a simultaneous measurement of the

yield, stability, and adaptability to use the MHPRVG, which is given by $M H P R V G=n / \sum_{j=1}^{n} \frac{1}{V_{g i j}}$, where $n$ is the number of environments where the clone $i$ was evaluated, and $V_{g i j}$ is the genotype value of the clone $i$ in environment $j$; it is expressed as a ratio of the local mean. Model 54 from SelegenRELM/BLUP software (Resende, 2007b) was used. The statistical model was given by $Y=X r+$ $Z g+W i+e$, where $Y$ is the data vector, $r$ is the vector of repetition effects (assumed to be fixed) added to the overall mean, $g$ is the vector of genotypic effects (assumed to be random), and $i$ is the vector or errors (random). The capital letters represent the incidence matrices for these purposes.

The statistics of stability and adaptability were compared using the Spearman correlation. The parameters analyzed were: (i) ecovalence $\left(\omega_{i}\right)$ from the Wricke method, (ii) confidence index $\left(I_{i}\right)$ from Annicchiarico, (iii) variance of absolute values of regression deviations $\left(\sigma_{d i}^{2}\right)$ and coefficient of regression of genotype $\left(\beta_{1}\right)$, (iv) the index of superiority $\left(p_{i}\right)$ by Lin and Binns (1988), (v) the weighted average of the absolute scores (AMMI) of the two first principal components for each genotype weighted by the percentage of variation explained by each component, and (vi) MHPRVG. The SAS CORR procedure (SAS Institute, 2002) was used in the Spearman analysis of correlation.

\section{RESULTS AND DISCUSSION}

Significant differences for the source of genotypic variation were observed at $1 \%$. The environment was significant at the $1 \%$ probability, indicating the existence of variability among locations. These significant differences between the locations can be explained by discrepancies in soil and climate conditions in the environments that were evaluated. Significant differences were observed at $1 \%$ probability by the F-test for GE interaction. This indicates that specifically adapted genotypes in more specific environments can be identified, which therefore justifies a detailed study of the adaptability and stability of genotypes (Table 1).

The experimental coefficient of variation was $10.1 \%$, and the ratio between the largest and smallest mean square residual was 2.9 (Table 1). According to Cruz et al. (2012), the approximate ratio of 7:1 between the highest and lowest mean square residual can be used as a threshold to assume homogeneity of error variances, allowing the combined analysis of variance from data of different environments.

The classifications of genotypes by different methods for adaptability and stability, as well as the order of TPH, are shown in Table 2 . The adaptability parameter $\left(\beta_{1}\right)$ from Eberhart 
and Russell (1966) was verified, and only two clones (RB937570 and RB957689) showed specific adaptability to favorable environments because their $\beta_{1}$ were significantly different (P $<0.05$ ) from one. Using the stability parameter $\left(\sigma_{d i}^{2}\right)$, seven clones (RB987935, RB935641, RB935686, RB987934, RB945065, RB957689, and RB977625) showed low stability, i.e., statistically different from zero using the F-test $(\mathrm{P}<0.05)$. Genotype RB957689 was the only clone with simultaneous specific adaptability and low stability.

Table 1. Analysis of variance, mean, coefficients of variation (CV), and the coefficient of the relationship between the larger and lower mean square error (MSE) for the variable tons of pol per hectare (TPH) of 15 genotypes in nine environments in Minas Gerais State, Brazil, in the crop seasons of 2005 and 2006.

\begin{tabular}{lcc}
\hline Source of variation & Degree of freedom & Mean square \\
\hline Blocks/environments & 18 & 5.8 \\
Environments (E) & 8 & $534.7^{* *}$ \\
Genotypes (G) & 14 & $50.0^{* *}$ \\
GE & 112 & $7.6^{* *}$ \\
Error & 252 & 3.4 \\
Means (tons/ha) & & 18.2 \\
CV $(\%)$ & & 10.1 \\
Larger MSE/lower MSE & & 2.9 \\
\hline
\end{tabular}

**P $<0.01$ by the F-test.

\begin{tabular}{|c|c|c|c|c|c|c|c|c|c|c|c|c|c|c|c|c|}
\hline \multirow[t]{2}{*}{ Genotypes } & \multicolumn{16}{|c|}{ Statistics $^{1}$} \\
\hline & TPH mean & Class $^{2}$ & $\beta_{1}$ & Class & $\sigma_{d i}^{2}$ & Class & $p_{i}$ & Class & $A M M I$ & Class & $\omega_{i}$ & Class & $I_{i}$ & Class & $M H P R V G$ & Class \\
\hline RB987935 & 20.71 & $1 \mathrm{st}$ & 1.01 & W & $2.21 *$ & $\mathrm{~L}$ & 1.74 & $2 \mathrm{nd}$ & 6.36 & 13 & 8.25 & 10 & 111.76 & $1 \mathrm{st}$ & 20.57 & $1 \mathrm{st}$ \\
\hline RB867515 & 20.44 & 2 nd & 1.2 & W & 0.46 & $\mathrm{H}$ & 1.64 & $1 \mathrm{st}$ & 4.13 & 8 & 5.32 & 6 & 110.26 & 2 nd & 20.27 & 2nd \\
\hline RB935641 & 19.81 & $3 \mathrm{rd}$ & 0.95 & W & $3.49 *$ & L & 4.53 & $3 \mathrm{rd}$ & 7.36 & 14 & 11.46 & 15 & 106.22 & $3 \mathrm{rd}$ & 19.71 & $3 \mathrm{rd}$ \\
\hline RB925211 & 19.16 & 4 & 1.14 & W & 0.89 & $\mathrm{H}$ & 5.27 & 4 & 5.47 & 11 & 5.61 & 7 & 102.93 & 4 & 19.05 & 4 \\
\hline RB935686 & 18.87 & 5 & 0.97 & W & $2.25^{*}$ & $\mathrm{~L}$ & 5.68 & 5 & 5.41 & 10 & 8.38 & 11 & 101.58 & 5 & 18.82 & 5 \\
\hline RB937570 & 18.65 & 6 & $1.24 *$ & $\mathrm{~S}$ & 0.52 & $\mathrm{H}$ & 7.17 & 6 & 2.44 & $3 \mathrm{rd}$ & 6.05 & 8 & 99.92 & 6 & 18.54 & 6 \\
\hline RB987934 & 18.24 & 7 & 0.8 & W & $2.12 *$ & $\mathrm{~L}$ & 9.67 & 7 & 6.27 & 12 & 9.36 & 13 & 98 & 7 & 18.26 & 7 \\
\hline RB956911 & 17.87 & 8 & 0.89 & W & 0.7 & $\mathrm{H}$ & 9.72 & 8 & 4.03 & 7 & 4.95 & 5 & 96.5 & 8 & 17.9 & 8 \\
\hline RB945065 & 17.62 & 9 & 0.88 & W & $2.27^{*}$ & $\mathrm{~L}$ & 11 & 9 & 3.12 & 6 & 8.85 & 12 & 94.85 & 9 & 17.65 & 9 \\
\hline RB72454 & 17.22 & 10 & 0.89 & W & 0.14 & $\mathrm{H}$ & 12.57 & 10 & 2.61 & 4 & 3.55 & 4 & 93.25 & 10 & 17.27 & 10 \\
\hline RB957689 & 17.08 & 11 & $1.22 *$ & * $\mathrm{S}$ & $1.24 *$ & $\mathrm{~L}$ & 13.51 & 11 & 4.26 & 9 & 7.52 & 9 & 90.07 & 14 & 16.97 & 11 \\
\hline RB977625 & 16.88 & 12 & 0.84 & W & $3.06^{*}$ & $\mathrm{~L}$ & 15.89 & 15 & 8.78 & 15 & 11.25 & 14 & 90.07 & 15 & 16.93 & 12 \\
\hline RB977619 & 16.85 & 13 & 1.08 & W & -0.16 & $\mathrm{H}$ & 14.02 & 12 & 2.9 & 5 & 2.65 & $1 \mathrm{st}$ & 90.47 & 12 & 16.85 & 13 \\
\hline RB977508 & 16.75 & 14 & 0.89 & W & 0.1 & $\mathrm{H}$ & 15.17 & 14 & 2.38 & 2 nd & 3.43 & $3 \mathrm{rd}$ & 90.75 & 11 & 16.76 & 15 \\
\hline RB987905 & 16.75 & 15 & 1 & $\mathrm{~W}$ & 0.23 & $\mathrm{H}$ & 14.99 & 13 & 1.84 & $1 \mathrm{st}$ & 3.36 & 2nd & 90.24 & 13 & 16.79 & 14 \\
\hline
\end{tabular}

${ }^{1} \beta_{1}$ and $\sigma_{d i}^{2}=$ Eberhart and Russel (1966); $p_{i}=$ Lin and Binns (1988); AMMI = Zobel et al. (1988); $\omega_{i}=$ Wricke (1965); $I_{i}^{d}=$ Annicchiarico (1992); MHPRVG = Resende (2007); ${ }^{2}$ Class = classification or order; $\mathrm{W}=$ wide adaptability; $\mathrm{S}=$ specific adaptability to favorable environment; $\mathrm{H}=$ high stability; $\mathrm{L}=$ low stability; ${ }^{*}, \mathrm{P}<0.05$ by the $t$-test for the hypothesis $\beta_{1}=1$ and by the F-test $\sigma_{d i}^{2}=0$.

The methods of Lin and Binns (1988), Annicchiarico (1992), and MHPRVG (Resende, 2007a) were similar in their classification of genotypes, with 100\% similarity for the first 10 positions. Furthermore, the same clones were in the first 10 positions relative to TPH (Table 2). The AMMI method (Zobel et al., 1988) classified the genotypes RB987905, RB977508, and RB937570 in first, second, and third place, respectively. These clones were the 15th, 14th, and 6th position relative to TPH (Table 2). A similar trend was observed by the method proposed by Wricke (1965), where the last three genotypes allocated positions in relation to TPH 
that were classified as the most stable for the three parameters (Table 2).

The similarities between the methods were further evaluated using Spearman correlation (Table 3). All of the pairwise correlations between the methods of Lin and Binns (1988), Annicchiarico (1992), and MHPRVG were positive and of high magnitude ( $\mathrm{P}>0.93$ ). Additionally, these methods were also highly positively correlated with TPH $(\mathrm{P}=0.9714, \mathrm{P}$ $=0.9429$, and $\mathrm{P}=0.9964$, respectively). The AMMI method obtained significant negative correlation ( $\mathrm{P}=-0.5535)$ with the MHPRVG method and the TPH $(\mathrm{P}=-0.5571)$. Significant positive correlation was shown with the stability parameter $\left(\sigma_{d i}^{2}\right)$ of Eberhart and Russell (1966) and the Wricke's method (1965), with magnitudes equal to 0.8218 and 0.7929 , respectively. The latter method, in turn, also demonstrated high correlation $(\rho=0.9513)$ with parameter $\sigma_{d i}^{2}$ Therefore, the AMMI and Wricke (1965) methods tended to select the most stable genotypes, coinciding with the stability parameter $\left(\sigma_{d i}^{2}\right)$ of Eberhart and Russell (1966) (Table 3).

Table 3. Correlation $(\rho)$ between stability and adaptability statistics from TPH in sugarcane.

\begin{tabular}{|c|c|c|c|c|c|c|c|}
\hline & $\beta_{1}$ & $\sigma_{d i}^{2}$ & $p_{i}$ & AMMI & $\omega_{i}$ & $I_{i}$ & TPH \\
\hline $\begin{array}{l}\text { MHPRVG } \\
\beta_{1} \\
\sigma_{d i}^{2} \\
p_{i} \\
A M M I \\
\omega_{i} \\
I_{i}\end{array}$ & -0.2722 & $\begin{array}{l}-0.4010 \\
-0.3841\end{array}$ & $\begin{array}{l}0.9750^{* *} \\
-0.3430 \\
-0.2540\end{array}$ & $\begin{array}{l}-0.5535^{*} \\
-0.1748 \\
0.8218 * * \\
-0.4036\end{array}$ & $\begin{array}{c}-0.4643 \\
-0.2677 \\
0.9513^{* *} \\
-0.3214 \\
0.7929^{* *}\end{array}$ & $\begin{array}{l}0.9357 * * \\
-0.2124 \\
-0.2312 \\
0.9643 * * \\
-0.3464 \\
-0.2714\end{array}$ & $\begin{array}{c}0.9964^{* *} \\
-0.2600 \\
-0.3992 \\
0.9714^{* *} \\
-0.5571^{*} \\
-0.4678 \\
0.9429^{* *}\end{array}$ \\
\hline
\end{tabular}

Similar conclusions were reported by Silva and Duarte (2006) in soybean, where the AMMI analysis showed stronger correlation with the Wricke (1965) and Eberhart and Russell (1966) methods. According to these authors, the correlation between these methods was due to the statistical principle similarity between the AMMI and Wricke (1965) methods, which are based on the genotypic contribution to the GE interaction, which also coincides with the agronomic stability parameter $\left(\sigma_{d i}^{2}\right)$ and Eberhart and Russell (1966) method. Furthermore, correlations between these same methods were reported by Gouvêa et al. (2012) and Mohammadi and Amri (2008) in evaluations with rubber tree and wheat, respectively. Scapim et al. (2010) also reported highly positive correlations between the method of Wricke (1965) and the parameter $\left(\sigma_{d i}^{2}\right)$ of Eberhart and Russell (1966) in popcorn.

Bajpai and Kumar (2005) stated that better results can be achieved using the AMMI method than models based on regression because the component of variability due to the GE interaction tends to be quite high in sugarcane. Regression models describe the suitable behavior of genotypes throughout the different environments and is only valid when the genotype response is linear. Therefore, the adaptability parameter of Eberhart and Russell (1966) did not correlate with any of the other methods (Table 3) because of the assumption of linearity.

Figure 2 shows the trend of the AMMI and Wricke (1965) methods, and it indicates that genotypes that are less productive as more stable. The classification indicates that as productivity increased, the parameters of the clones decreased. However, the opposite is observed in relation to the methods of Lin and Binns (1988), Annicchiarico (1992), and MHPRVG because these methods tend to select the most productive genotypes. 


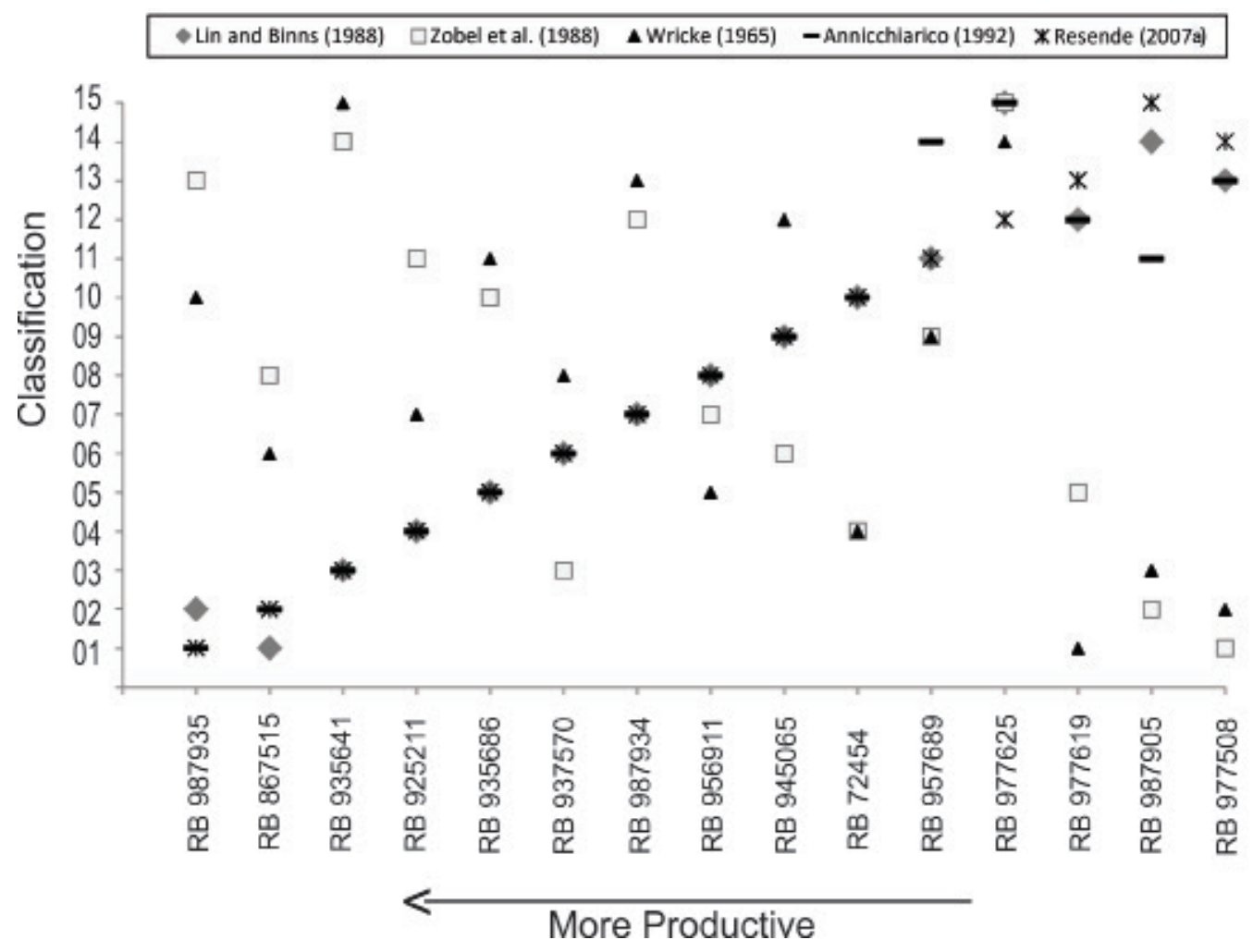

Figure 2. Classification plot of genotypes according to the methods of Lin and Binns (1988), Zobel et al. (1988), Wricke (1965), Annicchiarico (1992), and Resende (2007a).

In Figure 2, all clones were ranked at least once below the fifth place for the methods that were used, with the exception of genotypes RB977625 and RB957689. The display of the absolute values of the parameters of Eberhart and Russell (1966) in Figure 3 shows that the genotype RB977625 presented low stability, and genotype RB957689 presented low stability and adaptability specifically. Considering the statistical significance of the parameters, clones RB867515, RB925211, RB956911, RB72454, RB977619, RB977508, and RB987905 were the genotypes that simultaneously have wide adaptability and high stability (Figure 3). Among these, we highlight the merits of RB867515 and RB925211, which were assigned second and fourth place in TPH, respectively.

In this study, we noticed that the methods of Lin and Binns (1988), Annicchiarico (1992), and MHPRVG were highly correlated, indicating roughly similar results. Carbonell et al. (2007) reached the same conclusion when comparing these methods in evaluations of common bean lines. Bastos et al. (2007) and Oliveira et al. (2005) also showed similar results with sugarcane when they compared the MHPRVG, Lin and Binns (1988), and Silva and Duarte (2006) methods, and when they used soybeans to compare the Annicchiarico (1992) and Lin and Binns (1988) methods.

Yet, according to Bastos et al. (2007), Carbonell et al. (2007), and Oliveira et al. 
(2005), the MHPRVG method has the advantage of providing results on the same measurement scale as the character evaluation, which can be directly interpreted as genetic values. Another advantage is that the method penalizes the instability of genotypes through environments and simultaneously capitalizes responsiveness (adaptability) when the environment improves. This method is based on predicted genotypic values via mixed models and aggregates productivity, stability, and adaptability in a single statistic.

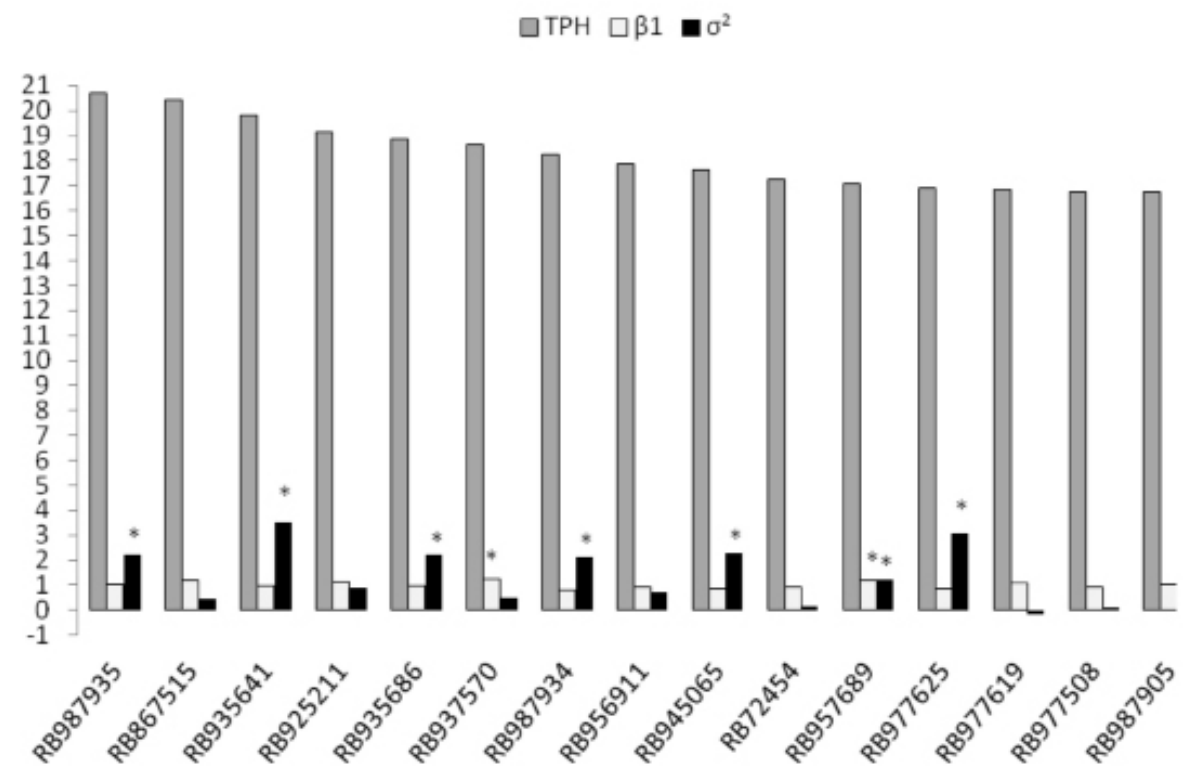

Figure 3. Comparison between ton of pol per hectare (TPH) and absolute values of the adaptability parameter $\left(\beta_{1}\right)$ and the stability parameter $\left(\sigma^{2}\right)$ (Eberhart and Russel, 1966) in 15 genotypes of sugarcane in nine environments. *, $\mathrm{P}<0.05$ by the $t$-test for the hypothesis $\beta_{1}=1$ and by the F-test $\sigma^{2}=0$.

Thus, it is clear that to improve the efficiency of sugarcane genotype adaptability and stability to different environments, it is important to use different methods in a complementary analysis. Therefore, we concluded that the MHPRVG method is preferable over the methods of Lin and Binns (1988) and Annicchiarico (1992) because it has the advantage of encompassing the concepts of productivity, adaptability, and stability, and it provides direct genetic values of individual genotypes. Compared to other methods, the Eberhart and Russell (1966) method is recommended because its parameter stability was similar to that of the AMMI and Wricke (1965) methods; however, its adaptability parameter produced parameters that were different from those of other methods, which is indicated by their low correlations. Thus, the MHPRVG (Resende, 2007a) and Eberhart and Russell (1966) methods are recommended.

\section{ACKNOWLEDGMENTS}

We would like to thank the mills and distilleries that are partners with RIDESA for the constant financial support for the breeding program development, and Fundação de Am- 
paro à Pesquisa do Estado de Minas Gerais (FAPEMIG), Financiadora de Estudos e Projetos (FINEP), Conselho Nacional de Desenvolvimento Científico e Tecnológico (CNPq), and Petrobras for the financial support for research projects.

\section{REFERENCES}

Annicchiarico P (1992). Cultivar adaptation and recommendation from alfalfa trials in Northern Italy. J. Genet. Breed. 46: 269-278.

Bajpai PK and Kumar R (2005). Comparison of methods for studying genotype $\mathrm{x}$ environment interaction in sugarcane. Sugar Tech. 7: 129-135.

Barbosa MHP, Resende MDV, Dias LAS, Barbosa GVS, et al. (2012). Genetic improvement of sugar cane for bioenergy: the Brazilian experience in network research with RIDESA. Crop Breed. Appl. Biotechnol. 12: 87-98.

Bastos IT, Barbosa MHP, Resende MDV, Peternelli LA, et al. (2007). Avaliação da interação genótipo x ambiente em cana-de-açúcar via modelos mistos. Pesq. Agropec. Trop. 37: 195-203.

Carbonell SAM, Chiorato AF, Resende MDV, Dias LAS, et al. (2007). Estabilidade de cultivares e linhagens de feijoeiro em diferentes ambientes no estado de São Paulo. Bragantia 66: 193-201.

Cargnelutti Filho A, Perecin D, Malheiros EB and Guadagnin JP (2007). Comparação de métodos de adaptabilidade e estabilidade relacionados à produtividade de grãos de cultivares de milho. Bragantia 66: 571-578.

CONAB Companhia Nacional de Abastecimento (2012). Levantamento de Safra: Cana-de-açúcar Available at: [http:// www.conab.gov.br/conteudos.php?a=1253\&t=] Accessed December 22, 2012.

Cruz CD (2006). Programa Genes: Biometria. Editora UFV, Viçosa.

Cruz CD, Regazzi AJ and Carneiro PCS (2012). Modelos Biométricos Aplicados ao Melhoramento Genético. Editora UFV, Viçosa.

dos Santos JM, Duarte Filho LSC, Soriano ML and da Silva PP (2012). Genetic diversity of the main progenitors of sugarcane from the RIDESA germplasm bank using SSR markers. Ind. Crop. Prod. 40: 145-150.

Eberhart SA and Russell WA (1966). Stability parameters for comparing varieties. Crop Sci. 6: 36-40.

Gouvêa LRL, Silva GAP, Verardi CK, Silva JQ, et al. (2012). Temporal stability of vigor in rubber tree genotypes in the pre- and post-tapping phases using different methods. Euphytica 186: 625-634.

Lin CS and Binns MR (1988). A Superiority Measure of Cultivar Performance for Cultivar x Location Data. Can. J. Plant Sci. Otawa, 193-198.

Mohammadi R and Amri A (2008). Comparison of parametric and non-parametric methods for selecting stable and adapted durum wheat genotypes in variable environments. Euphytica 159: 419-432.

Oliveira RA, Resende MDV, Daros E, Bespalhok Filho JC, et al. (2005). Genotypic evaluation and selection of sugarcane clones in three environments in the state of Paraná. Crop Breed. Appl. Biotechnol. 5: 426-434.

Pereira HS, Melo LC, Del Peloso MJ and Faria LC (2009). Comparação de métodos de análise de adaptabilidade e estabilidade fenotípica em feijoeiro-comum. Pesq. Agropec. Bras. 44: 374-383.

Resende MDV (2007a). Matemática e Estatística na Análise de Experimentos e no Melhoramento Genético. 1st edn. Embrapa Florestas, Colombo.

Resende MDV (2007b). Software SELEGEN-REML/BLUP: Sistema Estatístico e Seleção Genética Computadorizada Via Modelos Lineares Mistos. Embrapa Florestas, Colombo.

Rocha MM, Vello NA, Lopes ACA, Unêda-Trevisoli SH, et al. (2006). Correlações entre parâmetros de adaptabilidade e estabilidade da produtividade de óleo em soja. Ciênc. Rural 36: 772-777.

SAS Institute (2002). Software Version 9.1.3 of the SAS System for Windows. SAS Institute Inc, Cary.

Scapim CA, Pacheco CAP, do Amaral Júnior AT, Vieira RA, et al. (2010). Correlations between the stability and adaptability statistics of popcorn cultivars. Euphytica 174: 209-218.

Silva WCJ and Duarte JB (2006). Métodos estatísticos para estudo de adaptabilidade e estabilidade fenotípica em soja. Pesq. Agropec. Bras. 41: 23-30.

Verissimo MAA, Silva SDA, Aires RF, Daros E, et al. (2012). Adaptability and stability of early sugarcane genotypes in Rio Grande do Sul, Brazil. Pesq. Agropec. Bras. 47: 561-568.

Wricke G (1965). Zur Berechning der okovalenz bei sommerweizen und hafer. Z. Pflanzenzuchtung 52: 127-138.

Zobel RW, Wright MJ and Gauch HG (1988). Statistical-analysis of a yield trial. Agron. J. 80: 388-393. 